\title{
Manajemen Pengelolaan Bukti Digital Untuk Meningkatkan Aksesibilitas Pada Masa Pandemi Covid-19
}

\author{
Moch Bagoes Pakarti ${ }^{1 *}$, Dhomas Hatta Fudholi ${ }^{2)}$, Yudi Prayudi ${ }^{3)}$ \\ 1) Magister Teknik Informatika, Univesitas Islam Indonesia \\ 2, 3) Teknik Informatika, Univesitas Islam Indonesia \\ 1)bmovyz@gmail.com, ${ }^{2)}$ hatta.fudholi@uii.ac.id, ${ }^{3)}$ prayudi @uii.ac.id
}

\begin{abstract}
Covid-19 has a major impact on human life, including the process of managing digital evidence. Management of digital evidence requires special handling that can store and maintain the integrity of digital evidence. The current problem is there is no concept of storing digital evidence that can be accessed online in wider accessibility. Online digital evidence management is proposed as a solution to solve this problem. This concept is in the form of an online digital evidence management system that can be accessed anywhere and anytime using MD5 and SHA1 hash functions in order to maintain the properties of digital evidence so that it can be legally accepted. The problems with digital evidence management require a Management System for Digital Evidence that is suitable for application in Digital Forensics Laboratory. This research had successfully implemented the concept of online chain of custody. It is expected, with the concept of Online Digital Evidence Management, this digital evidence control and all activities related to it can be maintained and well documented. Moreover, it can reach a wider area accessed anywhere and any time and reduce the spread of Covid-19.
\end{abstract}

Keywords : Digital Evidence, Chain of Custody, Accessibility

\section{PENDAHULUAN}

Bukti merupakan informasi yang digunakan untuk membangun atau membantah sebuah fakta(Roscini, 2016). Barang bukti yang digunakan dapat berupa bukti digital atau bukti elektronik. Bukti elektronik dapat berupa komputer, telepon maupun hard disk. namun bukti digital berbentuk file yang tidak memiliki bentuk fisik, seperti: video, gambar digital, suara, log dan sebagainya. Tidak ada standar prosedur yang baku dalam hal penanganan kasus kejahatan komputer. Prosedur penanganan terdiri dari 5 langkah (Farmer \& Venema, 2005), yaitu: mengamankan dan mencegah Tempat Kejadian Perkara (TKP) tersebut didatangi oleh orang yang tidak berkepentingan (secure and isolate), mencatat apa saja yang ditemukan di TKP (record the scene), mencari bukti yang ada di TKP secara sistematis (conduct a systematic search for evidence), mengemas barang bukti (collect and package evidence) dan membuat chain of custody (maintain chain of custody).

bukti digital memiliki risiko tinggi untuk digandakan, disebarluaskan, dihapus dan dimanipulasi oleh siapa saja(Prayudi, 2014). Jika terjadi akses ilegal terhadap bukti digital tersebut maka bukti digital tersebut dapat tertolak di pengadilan. Semua file bukti digital yang akan dianalisis seharusnya disimpan dalam suatu tempat dengan prosedur penyimpanan tertentu. Prosedur penyimpanan bukti digital saat ini sudah ada namun masih menemui kendala yaitu: model bisnis yang berkaitan dengan siapa saja yang akan berinteraksi dengan bukti digital tersebut, penyimpanan informasi metadata bukti digital dan akses kontrol terhadap bukti digital tersebut(Prayudi et al., 2014).

Pada saat ini sistem dituntut agar dapat diakses dari mana saja dan kapan saja. Hal ini diperlukan untuk meningkatkan kinerja investigasi yang tidak terbatas waktu dan ruang serta mengurangi risiko menularnya covid-19 pada saat proses penanganan bukti digital.

Solusi untuk kendala tersebut adalah dengan membuat sebuah sistem pengelolaan bukti digital yang prosedur penyimpanannya sama seperti bukti elektronik. Namun sistem 
ini dapat diakses secara daring sehingga petugas dapat bekerja dari mana saja tanpa harus terjadi kontak fisik dengan petugas lainnya. Ketika bukti digital diunggah maka sistem akan mencatat kasus, jenis kejahatan dan siapa yang mengunggah bukti digital tersebut. Konsep ini akan memberikan pembatasan hak akses terhadap bukti digital tersebut sehingga tidak semua orang dapat mengaksesnya. Diharapkan dengan adanya konsep ini, dapat membuat bukti digital tersebut dapat memenuhi kriteria diterimanya suatu barang bukti di pengadilan (admissible, authentic, complete, reliable dan believable)(Prayudi \& SN, 2015).

Pada penelitian tentang solusi chain of custody yang dilakukan oleh (Cosic \& Baca, 2010) dan (Widatama \& Yudi Prayudi, 2017) telah memberikan solusi namun belum sepenuhnya sesuai dengan kebutuhan penanganan chain of custody, terutama sekali dalam hal aksebilitas bukti digital yang masih sangat terbatas yang tidak dapat menghadapi tantangan di era pandemi covid-19 dewasa ini. Oleh sebab itu, makalah ini memberikan salah satu solusi yang diusulkan untuk memberikan kontribusi bagi penanganan dan penyimpanan bukti digital secara daring.

\section{TINJAUAN PUSTAKA}

\subsection{Chain of custody}

Chain of custody menjadi bagian yang sangat penting dalam proses penanganan bukti digital karena dijadikan sebagai jaminan diterimanya suatu bukti digital. Pencatatan bukti digital dilakukan sebagai dokumentasi secara aktif, proses pendokumentasian barang bukti ini disebut chain of custody. Ditinjau dari cara pendokumentasiannya, proses chain of custody tanpa menggunakan aplikasi tertentu tidak efisien dan tidak bisa menjamin saat berlangsungnya prosedur forensik. Hal ini karena prosesnya masih manual dan belum terotomatisasi dengan aplikasi(Giova, 2011).

Adapun hal-hal apa saja yang harus didokumentasikan dalam sebuah kasus adalah dengan menggunakan sebuah rumus yaitu $5 \mathrm{~W} 1 \mathrm{H}$. Penggunaan formula ini merupakan formula standar yang sering digunakan oleh pihak kepolisian untuk membantu investigasi forensik(Cosic \& Baca, 2010). Rumus ini merupakan gabungan dari 6 pertanyaan dalam Bahasa Inggris yaitu: what, when, who, why, where dan how. Implementasi formula ini pada konsep Lemari pengelolaan bukti digital adalah sebagai berikut:

A. Who

Merumuskan siapa saja yang memiliki kewenangan untuk berinteraksi dengan sistem. Terdapat 3 petugas yang berinteraksi langsung maupun tidak langsung dengan bukti digital tersebut, yaitu:

1) First Responder

First responder berperan sebagai orang yang pertama mengunggah bukti digital ke dalam pengelolaan bukti digital. Ia juga memiliki akses untuk mengisi chain of custody.

2) Investigator

Investigator memiliki tugas untuk melakukan investigasi bukti digital terhadap kasus yang sedang ditangani. Ia hanya diberikan akses untuk mengunduh bukti digital dari sistem pengelolaan bukti digital.

3) Officer

Officer memiliki peran sebagai pengatur hak akses terhadap pengelolaan bukti digital. selain itu, ia memiliki akses untuk mencetak form chain of custody 


\section{B. When}

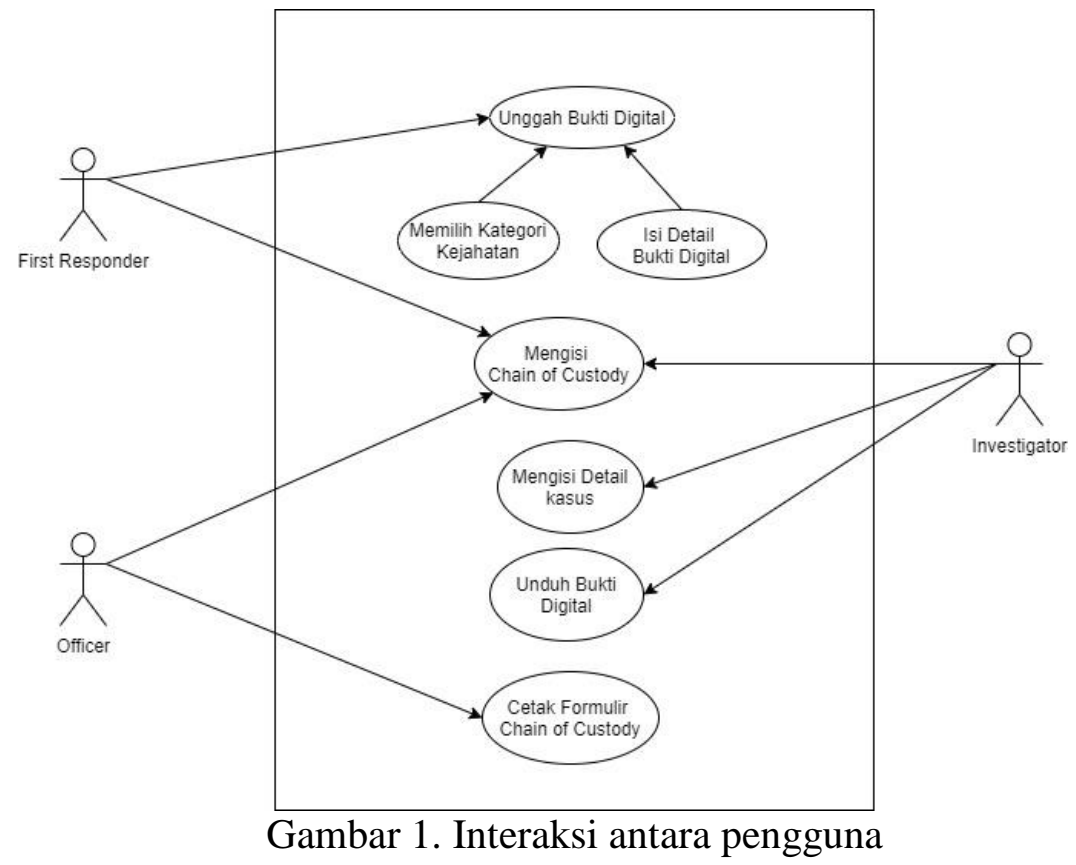

Digunakan untuk merumuskan waktu terjadinya proses mengunggah, melihat, mengunduh dan mengubah bukti digital yang ditangani (chain of custody).

C. Where

Merupakan informasi yang berisi tentang lokasi Tempat Kejadian Perkara (TKP) dimana dilakukan akuisisi bukti digital ataupun bukti elektronik.

D. What

Digunakan untuk menjelaskan kasus apa yang sedang ditangani.

\subsection{Prosedur Penanganan Bukti Digital}

Dalam prosedur forensika digital, terdapat prosedur dasar yang sering digunakan, yaitu: collection, examination, analysis dan reporting(Dogan \& Akbal, 2017), berikut adalah proses dari forensika digital:

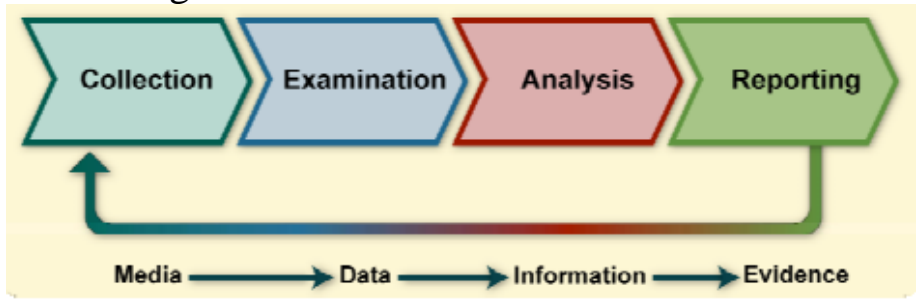

Gambar 2. Proses Utama Forensika Digital

Tahap Collection (Pengumpulan Data) meliputi aktivitas identifikasi sumber data yang relevan terkait kasus, pelabelan dan pencatatan. Dalam tahapan ini seluruh prosedur yang dilakukan harus sesuai dengan pedoman dan Standar Operasional Prosedur yang berlaku untuk menjaga integritas barang bukti digital. Termasuk di dalam nya melakukan verifikasi integritas data (Nilai Hash, MD5 atau SHA-1) dari data asli dan hasil akuisisi.

Tahap Examination (Pemeriksaan) meliputi aktivitas penggunaan tools atau perangkat lunak dan teknik tertentu untuk melakukan identifikasi dan ekstraksi informasi yang relevan. Tahap pemeriksaan dapat menggunakan tools otomatis atau melalui proses manual. 
Tahap Analysis (Analisis) merupakan aktifitas analisis terhadap hasil pemeriksaan untuk mendapatkan informasi yang berguna sehingga diperoleh kesimpulan.

Tahap Reporting (Pelaporan) merupakan aktivitas yang memuat tindakan, prsedur, alat yang digunakan dan memberikan rekomendasi perbaikan kebijakan dan petunjuk dalam aspek proses forensik.

\section{METODE PENELITIAN}

\subsection{Tempat penelitian}

Penelitian dilakukan pada laboratorium digital forensik Universitas Islam Indonesia (UII) yang berada di Yogyakarta. Laboratorium tersebut digunakan untuk menganalisis bukti digital dari kasus-kasus kejahatan yang melibatkan bukti elektronik dan bukti digital. Analisis yang dilaksanakan bertujuan untuk salah satu bentuk usaha untuk pembuktian kebenaran bukti digital yang ditemukan pada tempat kejadian perkara. Di dalam laboratorium terjadi aktifitas penyimpanan bukti digital, pemerikasaan, analisis dan mencetak formulir chain of custody.

Tabel 1 Jenis file bukti digital

\begin{tabular}{|l|l|l|}
\hline Jenis File & Ekstensi & Keterangan \\
\hline Image & DD, E01, 001, ad1, raw & $\begin{array}{l}\text { Hasil imaging dengan tool } \\
\text { forensik }\end{array}$ \\
\hline Multimedia & $\begin{array}{l}\text { mp4, mpeg, Avi, mkv, } \\
\text { mp3, wav, aac, }\end{array}$ & File video dan suara \\
\hline Gambar & $\begin{array}{l}\text { Jpg, jpeg, gif, png, bmp, } \\
\text { tiff }\end{array}$ & File gambar \\
\hline Teks & $\begin{array}{l}\text { Doc, docx, xls, xlsx, ppt, } \\
\text { pptx, rtf, txt, pdf }\end{array}$ & File office \\
\hline Archive & Rar, zip, iso & \\
\hline
\end{tabular}

Pada laboratorium digital forensik UII telah menangani berbagai macam jenis file bukti digital. Jenis file bukti digital dapat dilihat pada tabel 1. Pada tabel tersebut disebutkan jenis file yang dikelola oleh laboratorium digital forensik UII dengan berbagai macam ekstensi. Jenis file yang dikelola adalah jenis file image yang merupakan hasil imaging dengan menggunakan tool digital forensik seperti Encase, Autopsy, FTK Imager, Oxygen, Paraben dan Belkasoft. Hal ini bertujuan untuk memudahkan investigasi dan proses pembuatan laporan. Namun tidak menutup kemungkinan untuk mengelola jenis file yang lain karena terkadang bukti digital ditemukan di sosial media, email dan sebuah laman tertentu yang tidak memungkinkan untuk melakukan proses imaging.

\subsection{Alur Penelitian}

Penelitian ini bertujuan untuk membangun sebuah sistem yang dapat menyediakan akses pengelolaan bukti digital namun tetap menjaga keaslian bukti digital yang dikelola supaya hasil keluaran dari sistem ini yang berupa formulir chain of custody dapat diterima dalam persidangan. Untuk menjaga keaslian perlu diterapkan sebuah fungsi hash. Fungsi hash yang digunakan adalah fungsi SHA1 dan MD5. Saat bukti digital diunggah pada sistem maka bukti digital dicek nilai hashnya dan dicatat untuk kemudian akan dibandingkan dengan fungsi hash ketika bukti digital selesai di analisis dan dibawa di persidangan sebagai barang bukti. Dengan demikian bukti digital dapat dipastikan keasliannya karena tidak ada modifikasi pada bukti digital.

Pada gambar 3 dapat dilihat alur penelitian yang dimulai dengan studi pustaka pada penelitian sebelumnya kemudian memetakan kebutuhan data chain of custody nya. Tahap selanjutnya adalah merancang kategori bukti digital yang sesuai dengan hukum yang berlaku di Indonesia. Kemudian dilakukan tahap implementasi terhadap rancangan yang sudah dibuat. Selanjutnya dilakukan simulasi kasus dengan bukti digital yang ada pada 
laboratorium digital forensik UII agar proses pengujian yang dilakukan benar-benar valid. Pengujian dilakukan dengan membandingkan dengan sistem yang sudah ada.

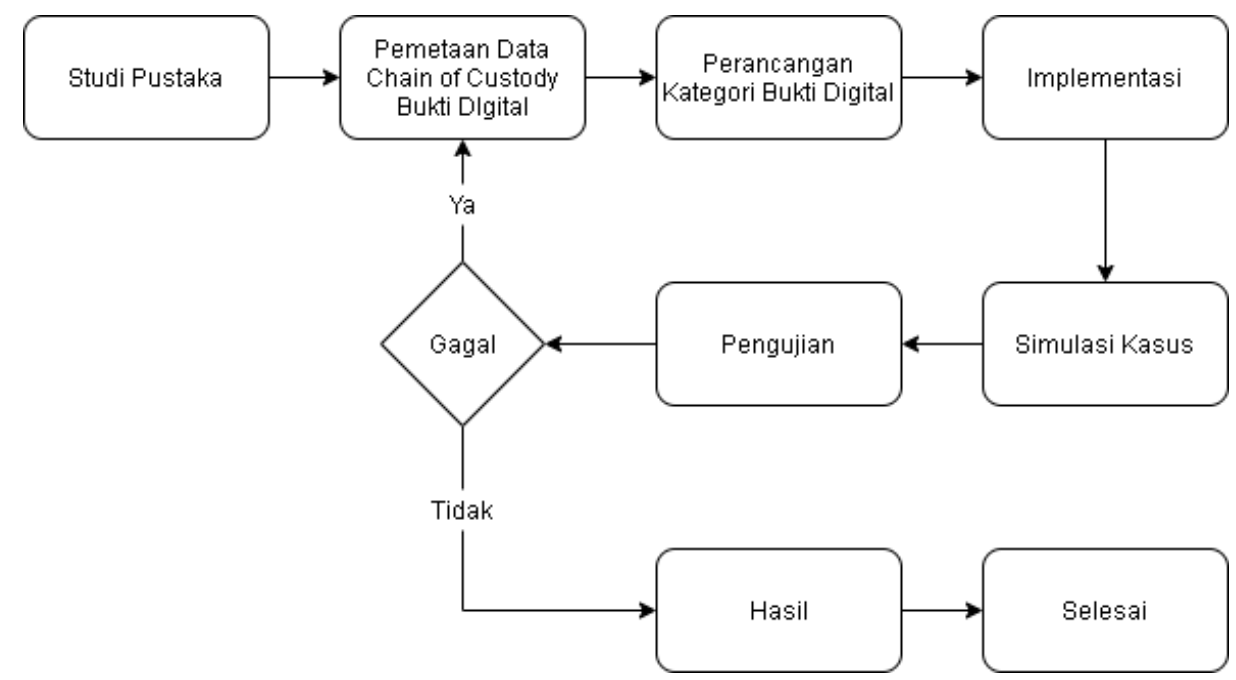

Gambar 3.Alur Penelitian

\subsection{Rancangan Sistem}

Berdasarkan konsep pengelolaan bukti digital yang telah dibuat, berikut adalah usulan model pada chain of custody dan penyimpanan informasi bukti digital. Bukti digital diawali dengan first responder mengunggah bukti digital kemudian diterima oleh officer yang kemudian akan diunduh oleh investigator untuk dianalisis dan disimpulkan hasilnya. Officer akan mengunduh formulir chain of custody yang dihasilkan oleh sistem untuk dibawa ke persidangan sebagai lampiran informasi bukti digital untuk memberikan gambaran alur penanganan bukti digital dan memberikan informasi keaslian bukti digital Gambar 4 menjelaskan tentang usulan model pada penyimpanan informasi metadata bukti digital.

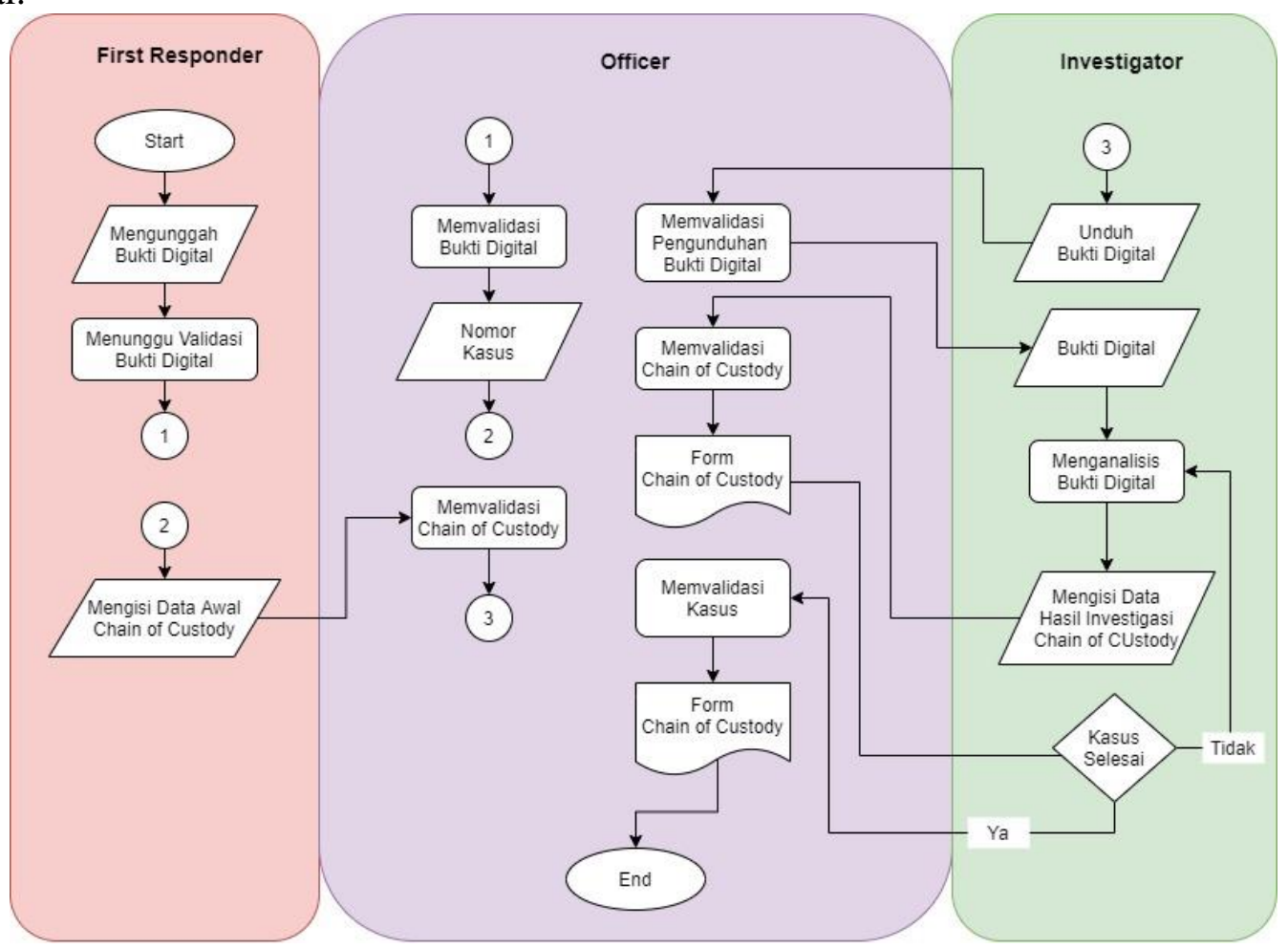

Gambar 4.Alur Penanganan bukti digital 
Pada tahap awal first responder mengunggah bukti digital kedalam sistem, kemudian setelah divalidasi oleh officer maka first responder dapat melanjutkan mengisi data awal chain of custody yang berupa detail bukti digital dan detail bukti elektronik, setelah data awal divalidasi maka investigator dapat mengunduh bukti digital yang sudah diunggah beserta data yang melekat pada bukti digital tersebut. Investigator menganalisis bukti digital dan mengisi data hasil investigasi ke dalam sistem. Setelah kasus selesai maka officer dapat memvalidasi kasus dan kemudian mencetak formulir chain of custody yang sudah lengkap. Chain of Costudy berisi detail bukti digital dan aktifitas dari para petugas terhadap sistem sehingga dapat digunakan pada persidangan.

Untuk memenuhi fungsi penyimpanan data bukti digital yang diunggah maka disusun sebuah database dengan struktur yang memiliki 5 tabel, yaitu; tabel record, kasus, user, jenis_kejahatan, dan bukti_digital.

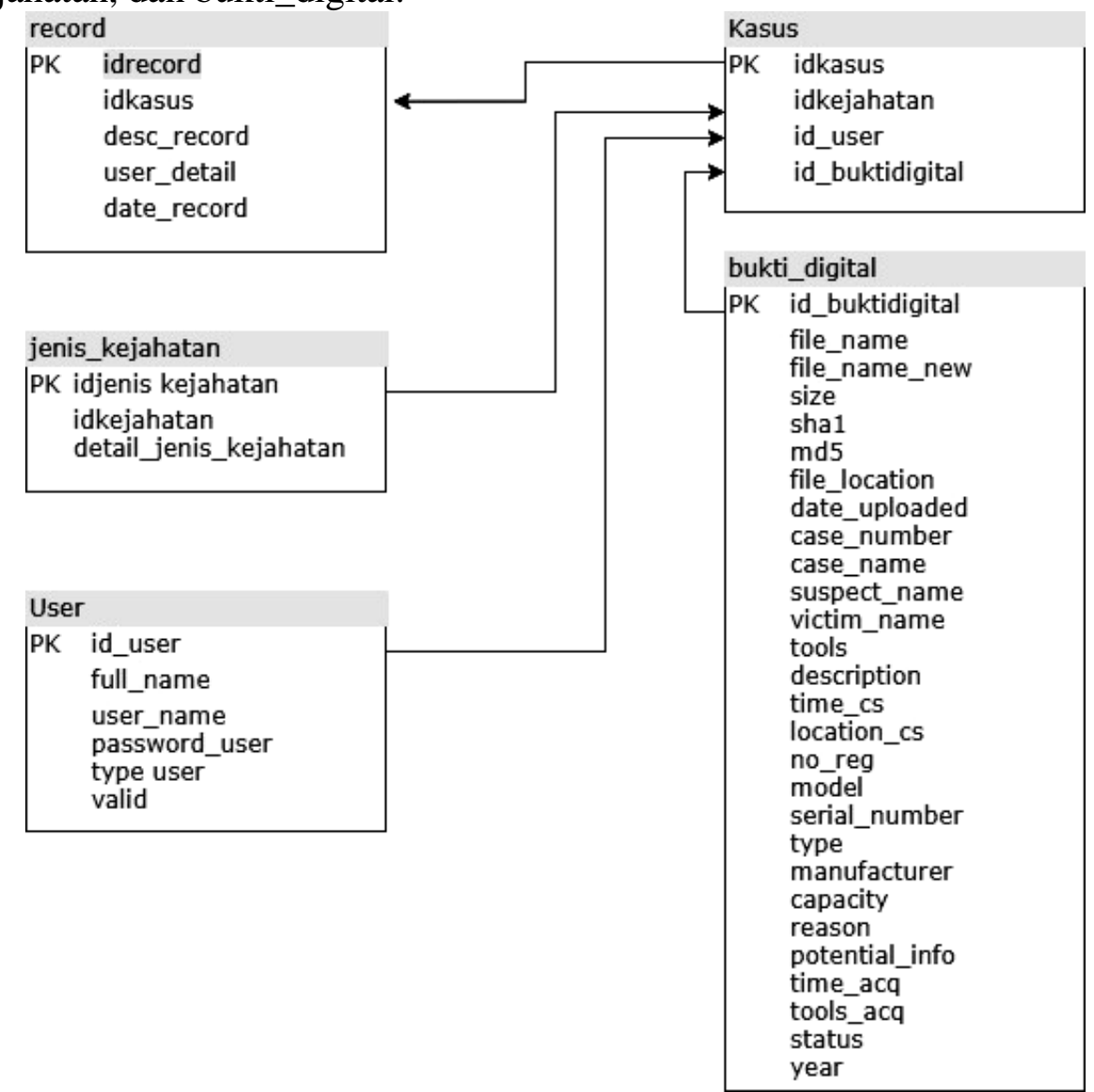

Gambar 5. Tabel Penyimpanan Pada Server

Tabel record menyimpan data chain of custody berupa riwayat penangan oleh petugas terhadap bukti digital yang dikelola. Tabel jenis_kejahatan menyimpan data kategori kejahatan yang telah disesuaikan dengan kategori kejahatan di Indonesia dan dapat disubah sesuai dengan kebutuhan. Tabel user berisi data petugas yang menggunakan aplikasi yang dirancang. Tabel bukti_digital berisi data detail bukti digital yang disimpan sedangkan tabel kasus menyimpan data kasus yang melibatkan bukti digital yang dikelola oleh laboratorium digital forensic UII.

Pada tahap selanjutnya adalah pembuatan kategori kejahatan yang disesuaikan dengan Kitab Undang-Undang Hukum Pidana (KUHP) yang merupakan dasar hukum pidana yang berlaku di Indonesia. Kategori tersebut dibagi menjadi tujuh kejahatan utama yaitu; Kejahatan terhadap harta benda Kejahatan terhadap jiwa seseorang, Kejahatan terhadap badan seseorang, Kejahatan terhadap kehormatan seseorang, Kejaahatan mengenai pemalsuan, Kejahatan mengenai kesusilaan dan Kejahatan terhadap negara. 
Untuk meningkatkan aksesibilitas dan mengurangi kontak fisik terkait pandemi covid-19 maka sistem yang dirancang harus dapat diakses dimana saja dan kapan saja dengan membuat sistem tersebut terhubung dengan internet. Pada gambar 5 dapat diliat konfigurasi IP server dimana server terhubung pada jaringan dengan IP lokal 192.168.1.120 sedangkan untuk memenuhi kebutuhan akses yang lebih luas maka server duihubungkan dengan internet dengan IP publik 182.253.115.42 yang dapat diakses dari mana saja.

Dengan kemampuan sistem yang dapat diakses melalui internet maka kontak fisik antara para petugas dapat diminimalisir. Petugas dapat melaksanakan tugasnya masing masing dengan tetap dirumah ataupun dilapangan. Tentu saja hal ini sesuai dengan anjuran pemerintah untuk melakukan pekerjaan dari rumah atau work from home dengan tujuan untuk memutus rantai penyebaran covid-19.

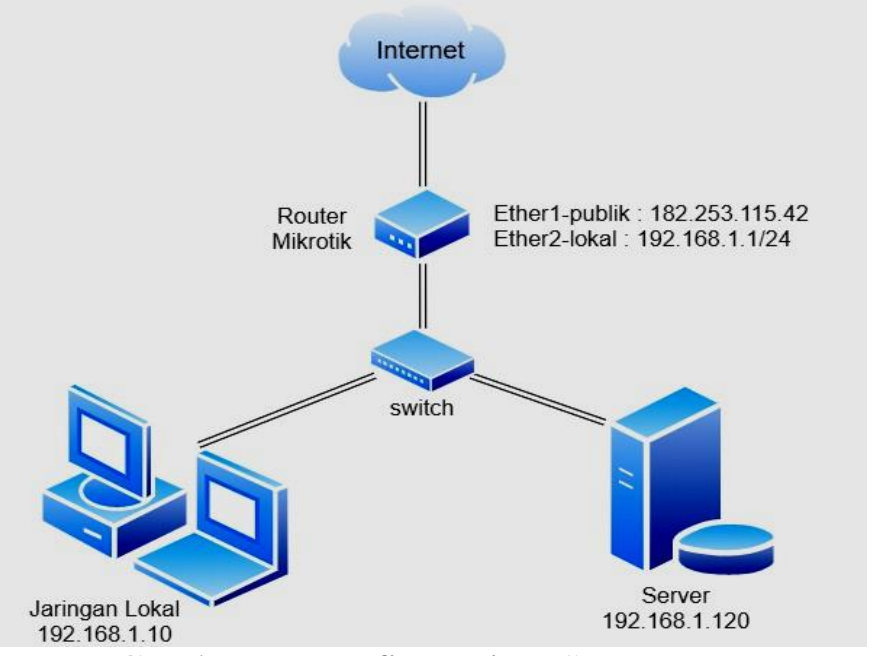

Gambar 6. Konfigurasi IP Server

\section{HASIL DAN PEMBAHASAN}

Pada penelitian ini pengujian dilakukan dengan metode black box dan membandingkan hasil keluaran sistem yang diusulkan dengan sistem sistem yang sudah ada sebelumnya sebagai acuan supaya sistem tetap memiliki fungsi dan peran yang sesuai dengan kebutuhan. Tahapan pengujian dapat dilihat pada table 2 .

Tabel 2 Tahap Pengujian

\begin{tabular}{|c|c|c|}
\hline Kelas Uji & Butir Uji & Jenis Pengujian \\
\hline Sign In & Verifikasi Password & Black Box \\
\hline \multirow[t]{2}{*}{ Pengolahan Data Pengguna } & Tambah Data Pengguna & Black Box \\
\hline & Ubah Data Pengguna & Black Box \\
\hline \multirow{2}{*}{$\begin{array}{l}\text { Pengolahan Data Bukti Digital } \\
\text { (first responder) }\end{array}$} & Unggah Bukti Digital & Black Box \\
\hline & $\begin{array}{l}\text { Input Data Kelengkapan Bukti } \\
\text { Digital }\end{array}$ & Black Box \\
\hline \multirow{2}{*}{$\begin{array}{l}\begin{array}{l}\text { Pengolahan Data } \\
\text { (officer) }\end{array} \\
\end{array}$} & Aktivasi Status Kasus & Black Box \\
\hline & Unduh Form Chain of Custody & Black Box \\
\hline \multirow{2}{*}{$\begin{array}{l}\begin{array}{l}\text { Pengolahan Data } \\
\text { (investigator) }\end{array} \\
\end{array}$} & Unduh Bukti Digital & Black Box \\
\hline & Melengkapi data kasus & Black Box \\
\hline Pengolahan Data Kasus & $\begin{array}{lll}\text { Perubahan } & \text { Data } & \text { Statistik } \\
\text { Dashboard } & & \\
\end{array}$ & Black Box \\
\hline $\begin{array}{l}\text { Pengolahan Data Interaksi Bukti } \\
\text { Digital }\end{array}$ & $\begin{array}{l}\text { Penambahan Data Interaksi Bukti } \\
\text { Digital }\end{array}$ & Black Box \\
\hline Keaslian data & $\begin{array}{l}\text { Membandingkan hasil fungsi hash } \\
\text { dari sistem yang disusulkan } \\
\text { dengan fungsi hash sistem lain }\end{array}$ & $\begin{array}{l}\text { Perbandingan Hasil Fungsi } \\
\text { Hash SHA1 dan MD5 }\end{array}$ \\
\hline $\begin{array}{l}\text { Kelengkapan data chain of } \\
\text { custody }\end{array}$ & $\begin{array}{l}\text { Membandingkan kelengkapan } \\
\text { formulir chain of custody }\end{array}$ & $\begin{array}{l}\text { Perbandingan Kelengkapan } \\
\text { data dengan kebutuhan }\end{array}$ \\
\hline
\end{tabular}


Pengujian black box berfokus pada persyaratan fungsional yang dimiliki perangkat lunak dengan mengamati proses input data yang dilakukan serta mengamati hasil output yang dihasilkan. Selain itu pengujian juga dilakukan dengan membandingkan hasil keluaran sistem yang dirancang dengan sistem yang sudah ada sebelumnya baik secara kelengkapan fungsi pencatatan pada form chain of custody maupun hasil keluaran fungsi hash MD5 dan SHA1 yang dihasilkan oleh tools tertentu.

\section{Hasil pengujian}

Tabel 3 Perbandingan Hasil Nilai hash pada File 19111200113UQ0F.mp4

\begin{tabular}{|c|c|}
\hline \multicolumn{2}{|c|}{ Nilai Hash Sistem Pengelolaan Bukti Digital } \\
\hline SHA1 & edffba1cfb0d90f1dc71f099526b0bcc06a929c3 \\
\hline MD5 & b5ea72348b6250de46876a2b9ad38504 \\
\hline \multicolumn{2}{|c|}{ Nilai Hash Autopsy } \\
\hline SHA1 & edffba1cfb0d90f1dc71f099526b0bcc06a929c3 \\
\hline MD5 & b5ea72348b6250de46876a2b9ad38504 \\
\hline \multicolumn{2}{|c|}{ Nilai Hash sha1-online.com } \\
\hline SHA1 & edffba1cfb0d90f1dc71f099526b0bcc06a929c3 \\
\hline MD5 & b5ea72348b6250de46876a2b9ad38504 \\
\hline \multicolumn{2}{|c|}{ Kesimpulan Hasil Perbandingan Nilai Hash } \\
\hline SHA1 & Sama \\
\hline MD5 & Sama \\
\hline
\end{tabular}

Pengujian nilai hash pada bukti digital dengan nama 19111200113UQ0F file dengan jenis mp4. Tabel 3 menunjukkan perbandingan hasil nilai hash antara sistem pengelolaan bukti digital dengan hasil nilai hash dari Autopsy dan shal-online. Pada Pengujian nilai hash dengan metode SHAl sistem yang dirancang menghasilkan nilai hash edffba1cfb0d90f1dc71f099526b0bcc06a929c3, kemudian file yang sama diunggah pada aplikasi Autopsy menghasilkan nilai hash edffbalcfb0d90fldc71f099526b0bcc06a929c3 demikian juga dengan laman shal-online.com menghasilkan nilai hash yang sama yaitu edffba1cfb0d90f1dc71f099526b0bcc06a929c3.

Kemudian penguian selanjutnya dilakukan dengan membandingkan nilai hash MD5 yang dihasilkan oleh system yang dirancang. Sistem yang dirancang menghasilkan nilai hash b5ea72348b6250de46876a2b9ad38504, file yang sama diunggah pada aplikasi autopsy menghasilkan nilai hash b5ea72348b6250de46876a2b9ad38504 kemudian pada laman sha1-online.com juga menghasilkan nilai hash yang sama yaitu b5ea72348b6250de46876a2b9ad38504. Hal ini menunjukkan bahwa sistem dapat menghasilkan fungsi hash yang sesuai dengan standar dan dapat diterima keabsahannya.

Pengamatan selanjutnya dilakukan dengan menguji kelengkapan data chain of custody pada sistem yang dirancang dengan sistem yang sudah ada. Dari hasil pengamatan yang dilakukan dapat diketahui bahwa sistem yang diusulkan memiliki kelengkapan data yang lebih banyak dari penelitian sebelumnya. Data baru yang disimpan pada sistem yang baru ialah; Kategori Kejahatan, Deskripsi tools, Nama first responder, Nama Institusi dan Nomor kasus. 


\begin{tabular}{|c|c|}
\hline \multicolumn{2}{|c|}{ CHAIN OF CUSTODY OF DIGITAL EVIDENCE } \\
\hline \multicolumn{2}{|c|}{ To be completed by First Responder and Investigator } \\
\hline \multicolumn{2}{|l|}{ Crime Scene } \\
\hline Category & Kejahatan terhadap kehormatan seseorang \\
\hline Suspect & Dina Rahmawati \\
\hline Victim & Rian Septiawan \\
\hline Location & Sleman \\
\hline Time & 14.00 \\
\hline Tools (Live Forensics) & autopsy \\
\hline Tools Description & live forensics \\
\hline First Responder & bagoes pakarti \\
\hline Institution & UII \\
\hline Tools Description & live forensics \\
\hline \multicolumn{2}{|l|}{ Electronic Evidence } \\
\hline Register Number & SL22155 \\
\hline Type & Smartphone \\
\hline Model & Xiami Note 10 \\
\hline Manufacture & Xiaomi \\
\hline Serial Number & 25104866541285 \\
\hline Foreclosure Reasons & Alat Untuk Mengupload Status Pencemaran \\
\hline \multicolumn{2}{|l|}{ Digital Evidence } \\
\hline Case Number & SL20200712 \\
\hline File Name & 07072020.E01 \\
\hline Time (Acquisition) & $02 / 02 / 2020$ \\
\hline Device (Acquisition) & Autopsy \\
\hline Size (Byte) & 66726 \\
\hline Hashing MD5 & e8ac66df253f5904b3db8744f30b98ea \\
\hline Hashing SHA1 & $276548 \mathrm{~b} 070 \mathrm{~d} 46 \mathrm{fde} 3 \mathrm{~b} 3 \mathrm{~d} 9 \mathrm{afc} 82 \mathrm{c} 63 \mathrm{e} 23 \mathrm{e} 6 \mathrm{cfe} 603$ \\
\hline Source & C:xampp $\backslash$ tmp $\backslash p h p 50 B 0 . t m p$ \\
\hline Potential Information & Upload dengan aplikasi Instagram \\
\hline Date Uploaded & 25-07-2020 03:09 \\
\hline Validator & Officer \\
\hline
\end{tabular}

Gambar 7. Formulir Chain of Custody

Pada gambar 7 merupakan formulir chain of custody yang berisikan detail kasus yang dihasilkan oleh sistem. Pada formulir tersebut dibagi menjadi tiga bagian data, yakni crime scene yang berisi detail kasus kejahatan, kemudian bagian kedua merupakan electronic evidence yang berisi detail bukti elektronik atau perangkat yang menyimpan bukti digital dan bagian ketiga digital evidence yang berisi detail dari bukti digital yang dikelola. Pada form ini dapat ditemukan data Kategori Kejahatan, Deskripsi tools, Nama first responder, Nama Institusi dan Nomor kasus yang merupakan data baru pada sistem yang dibuat.

Tabel 3 Perbandingan Chain of Custody dengan Peneltian Sebelumnya

\begin{tabular}{|c|l|c|c|c|c|}
\hline \multirow{2}{*}{ No. Informasi } & \multicolumn{4}{|c|}{ Ketersediaan Dalam Form } \\
\hline & & \multicolumn{3}{|c|}{ Sistem Baru } & \multicolumn{2}{c|}{ Penelitian Sebelumnya } \\
\hline & & Ada & Tidak Ada & Ada & Tidak Ada \\
\hline Informasi Olah TKP & & & & \\
\hline 1. & Nama kasus & $\checkmark$ & & $\checkmark$ & \\
\hline 2. & Kategori kejahatan & $\checkmark$ & & & $\checkmark$ \\
\hline 3. & Nama tersangka & $\checkmark$ & & $\checkmark$ & \\
\hline 4. & Nama korban & $\checkmark$ & & $\checkmark$ & \\
\hline 5. & Lokasi & $\checkmark$ & & $\checkmark$ & \\
\hline 6. & Waktu & $\checkmark$ & & $\checkmark$ & \\
\hline 7. & Nama tools (live forensic) & $\checkmark$ & & $\checkmark$ & \\
\hline 8. & Deskripsi tools & $\checkmark$ & & & $\checkmark$ \\
\hline 9. & Nama first responder & $\checkmark$ & & & $\checkmark$ \\
\hline 10. & Nama Institusi & $\checkmark$ & & & $\checkmark$ \\
\hline \multicolumn{2}{|c|}{ Jabatan } & & $\checkmark$ & $\checkmark$ & \\
\hline Informasi Bukti Elektronik & & & & \\
\hline 10. & Nomor registrasi & $\checkmark$ & & $\checkmark$ & \\
\hline
\end{tabular}




\begin{tabular}{|c|l|c|c|c|c|}
\hline \multirow{2}{*}{ No. Informasi } & \multirow{5}{|c|}{ Ketersediaan Dalam Form } \\
\hline & & \multicolumn{3}{|c|}{ Sistem Baru } & \multicolumn{2}{c|}{ Penelitian Sebelumnya } \\
\hline & & Ada & Tidak Ada & Ada & Tidak Ada \\
\hline 11. & Tipe & $\checkmark$ & & $\checkmark$ & \\
\hline 12. & Nama Model & $\checkmark$ & & $\checkmark$ & \\
\hline 13. & Nama Produsen & $\checkmark$ & & $\checkmark$ & \\
\hline 14. & Nomor serial & $\checkmark$ & & $\checkmark$ & \\
\hline & Deskripsi Fisik & & $\checkmark$ & $\checkmark$ & \\
\hline 15. & Alasan utama penyitaan & $\checkmark$ & & $\checkmark$ & \\
\hline Akuisisi Bukti Digital & & & & \\
\hline 16. & Waktu & $\checkmark$ & & $\checkmark$ & \\
\hline 17. & Nama tools & $\checkmark$ & & $\checkmark$ & \\
\hline 18. & Tanggal & $\checkmark$ & & $\checkmark$ & \\
\hline 19. & Nama Petugas & $\checkmark$ & & $\checkmark$ & \\
\hline 20 & Device & $\checkmark$ & & $\checkmark$ & \\
\hline Informasi Bukti Digital & & & & \\
\hline 21. & Nomor kasus & $\checkmark$ & & & \\
\hline 22. & Nama file & $\checkmark$ & & $\checkmark$ & \\
\hline 23. & Ukuran file & $\checkmark$ & & $\checkmark$ & \\
\hline 23. & Nilai hash (SHA1) & $\checkmark$ & & $\checkmark$ & \\
\hline 24. & Nilai hash (MD5) & $\checkmark$ & & $\checkmark$ & \\
\hline 25 & Nilai hash (SHA 256) & & $\checkmark$ & $\checkmark$ & \\
\hline 26. & Lokasi penyimpanan & $\checkmark$ & & $\checkmark$ & \\
\hline 27. & Lokasi penyimpanan & $\checkmark$ & & $\checkmark$ & \\
\hline 28 & Tanggal/waktu simpan & $\checkmark$ & & $\checkmark$ & \\
\hline & Validator & $\checkmark$ & & $\checkmark$ & \\
\hline 29. & Informasi yang ingin didapatkan & $\checkmark$ & & \\
\hline 30. & Status kasus & $\checkmark$ & & \\
\hline
\end{tabular}

Dengan rancangan sistem yang diusulkan, petugas dapat melaksanakan tugas mereka masing-masing tanpa perlu datang ke laboratorium forensika digital UII dan melakukan kontak fisik dengan petugas yang lain sehingga dapat membatu untuk memutus rantai penyebaran covid-19.

First Responder dapat mengunggah bukti digital, Investigator mengunduh bukti digital dan officer mengunduh formulir chain of custody melalui sistem yang disediakan secara daring melalui internet. Perbandingan ini dapat dilihat pada tabel 4.

Tabel 4 Perbandingan Aksesibilitas Bukti Digital

\begin{tabular}{|c|c|c|c|}
\hline \multirow{2}{*}{ No } & \multirow{2}{*}{ Aktifitas } & \multicolumn{2}{|c|}{ Sistem Pengelolaan Bukti Digital } \\
\hline & & Penelitian sebelumnya & Sistem baru \\
\hline 1. & $\begin{array}{l}\text { Penyerahan } \\
\text { Bukti Digital }\end{array}$ & $\begin{array}{l}\text { 1. Membutuhkan waktu yang lama } \\
\text { 2. Berisiko rusak atau hilangnya data dalam } \\
\text { perjalanan. } \\
\text { 3. Memungkinkan terjadinya sabotase fisik } \\
\text { oleh pihak tertentu. }\end{array}$ & $\begin{array}{l}\text { Dilakukan secara daring, } \\
\text { meminimalisir risiko yang ada. }\end{array}$ \\
\hline 2. & $\begin{array}{l}\text { Investigasi } \\
\text { Bukti Digital }\end{array}$ & $\begin{array}{l}\text { 1. Memerlukan waktu untuk datang ke } \\
\text { laboratorium. } \\
\text { 2. Investigasi terbatas dengan peralatan yang } \\
\text { ada di laboratorium. } \\
\text { 3. Investigator harus membawa perlengkapan } \\
\text { yang dimiliki ke laboratorium jika } \\
\text { investigasi dilakukan di laboratorium }\end{array}$ & $\begin{array}{l}\text { Data dapat diakses secara daring dan } \\
\text { diinvestigasi di laboratorium milik } \\
\text { pribadi. Sehingga dapat } \\
\text { menggunakan perlengakapan pribadi } \\
\text { investigator yang lebih canggih. }\end{array}$ \\
\hline 3. & $\begin{array}{l}\text { Penyimpanan } \\
\text { Bukti digital }\end{array}$ & $\begin{array}{l}\text { Bukti digital disimpan pada penyimpanan } \\
\text { lokal sehingga hanya bisa diakses di } \\
\text { laboratorium bukti digital. }\end{array}$ & $\begin{array}{l}\text { Bukti digital disimpan pada server } \\
\text { dan dapat diakses dari mana saja dan } \\
\text { kapan saja. }\end{array}$ \\
\hline 4. & $\begin{array}{l}\text { Unduh } \\
\text { formulir chain } \\
\text { of custody }\end{array}$ & $\begin{array}{l}\text { Harus datang langsung ke laboratorium } \\
\text { meskipun file sudah berupa pdf. }\end{array}$ & $\begin{array}{l}\text { Dapat diunduh kapanpun dan } \\
\text { dimanapun sehingga persiapan untuk } \\
\text { persidangan menjadi lebih efisien. }\end{array}$ \\
\hline 5. & $\begin{array}{l}\text { Kontak Fisik } \\
\text { antar petugas }\end{array}$ & $\begin{array}{l}\text { Harus menerapkan protokol pencegahan } \\
\text { penularan Covid-19. }\end{array}$ & Tidak ada kontak fisik. \\
\hline
\end{tabular}


Hal ini memberikan solusi atas masalah dan risiko yang dihadapi para petugas pada sistem yang sudah ada selama ini. Masalah yang dihadapi dapat berhubungan langsung dengan bukti digital maupun terhadap pribadi petugas itu sendiri. Hal ini perlu diperhatikan karena sangat berpengaruh dalam keberlangsungan proses investigasi kasus dan proses persidangan terhadap kasus yang terkait pada bukti digital.

\section{KESIMPULAN DAN SARAN}

\subsection{Kesimpulan}

Berdasarkan data yang didapat dari proses implementasi hingga ke tahap pengujian, maka didapat beberapa kesimpulan, yaitu:

1. Sistem pengelolaan bukti digital yang diusulkan dapat meningkatkan aksesibilitas bukti digital yang sangat berpengaruh dalam proses investigasi. Mulai dari tahap penyerahan bukti digital, unduh bukti digital penyimpanan hingga proses unduh formulir chain of custody dilakukan secara daring tanpa harus datang ke laboratorium forensika digital sehingga proses investigasi berjalan lebih cepat dan meminimalisir risiko kerusakan pada bukti digital dan keselamatan petugas.

2. Sistem yang diusulkan dapat digunakan secara bersamaan dan terpisah tanpa perlu bergantian antara pengguna satu dengan pengguna yang lain dalam satu perangkat yang sama.

3. Dengan sistem yang dapat diakses secara daring maka petugas dapat bekerja tanpa harus datang ke laboratorium forensika digital UII dan menghindari kontak antar petugas sehingga dapat membantu memutus rantai penyebaran Covid-19.

\subsection{Saran}

Adapun saran-saran yang perlu diberikan dalam penelitian ini adalah:

1. Memperkaya komponen pada dashboard dengan informasi yang lebih variatif dan menarik serta dilengkapi dengan sistem analisis dari data yang sudah dikumpulkan sehingga dapat digunakan sebagai sistem pendukung keputusan.

2. Menyediakan enkripsi data bukti digital untuk meningkatkan keamanan dan akuntabilitas bukti digital yang dikelola.

\section{DAFTAR PUSTAKA}

Cosic, J., \& Baca, M. (2010). Do we have full control over integrity in digital evidence life cycle? Proceedings of the International Conference on Information Technology Interfaces, ITI, 429-434.

Dogan, S., \& Akbal, E. (2017). Analysis of mobile phones in digital forensics. 2017 40th International Convention on Information and Communication Technology, Electronics and Microelectronics, MIPRO 2017 - Proceedings, 1241-1244. https://doi.org/10.23919/MIPRO.2017.7973613

Farmer, D., \& Venema, W. (2005). Forensic Discovery. http://www.informit.com/store/forensic-discovery-paperback-9780321703255

Giova, G. (2011). Improving Chain of Custody in Forensic Investigation of Electronic Digital Systems. International Journal of Computer Science and Network Security, 11(1), 1-9. http://paper.ijcsns.org/07_book/201101/20110101.pdf

Prayudi, Y. (2014). Problema dan Solusi Digital Chain Of Custody. Seminar Nasional Aplikasi Teknologi Informasi (Senasti).

Prayudi, Y., Ashari, A., \& K Priyambodo, T. (2014). Digital Evidence Cabinets: A Proposed Framework for Handling Digital Chain of Custody. International Journal of Computer Applications. https://doi.org/10.5120/18781-0106

Prayudi, Y., \& SN, A. (2015). Digital Chain of Custody: State of The Art. International 
Journal of Computer Applications, 114(5), 1-9. https://doi.org/10.5120/19971-1856

Roscini, M. (2016). Digital evidence as a means of proof before the international court of justice. Journal of Conflict and Security Law, 21(3), 541-554. https://doi.org/10.1093/jcsl/krw016

Widatama, K., \& Yudi Prayudi. (2017). Konsep Lemari Penyimpanan Bukti Digital Menggunakan Struktur Bahasa XML. Seminar Nasional Informatika Dan Aplikasinya Ke-3, September, 23. 